\title{
Suorakylvettyjen kevätviljojen ja rypsin kasvu
}

\author{
Hannu Känkänen \\ Maa- ja elintarviketalouden tutkimuskeskus, Kasvintuotannon tutkimus, Kasvinviljely ja biotekniikka, \\ 31600 Jokioinen, hannu.kankanen@mtt.fi
}

\section{Johdanto}

Viljelijät ovat hyvin kiinnostuneita suorakylvöstä, ennen kaikkea muokkauksen pois jäämisestä aiheutuvien työaika- ja kustannussäästöjen vuoksi. Muokkaamattomuus muuttaa kuitenkin suuresti itämiseen, orastumiseen ja myöhempään kasvuun vaikuttavia oloja. MTT:1lä tutkittiin suorakylvöä jo 1980-luvulla, mutta vain syysviljojen viljelyssä. Suorakylvöinnostuksen alkaessa muutama vuosi sitten kasvaa, oli kevätviljan suorakylvöstä olemassa käytännön kokemuksia lähinnä kevyiltä mailta. Kevätviljan suorakylvöä on jonkin verran tutkittu jo viime vuosikymmenen puolella, ja kahden vuoden ajan aihetta on tutkittu nykyisessä laajuudessaan. Tutkimushanke, johon tässä artikkelissa esitettävät koetulokset sisältyvät, selvittää kevätviljan suorakylvöä hienojakoisilla mailla (savimaat). Lisäksi rypsin suorakylvöä tutkitaan hankkeessa, jonka tavoitteena on löytää uusia ratkaisuja rypsin kasvuun lähdön parantamiseksi.

\section{Aineisto ja menetelmät}

Kaikki tässä esiteltävät kokeet on tehty hienojakoisella savimaalla. Tavanomainen kylvö on tehty kynnetyn maan jyrsinkylvönä ja suorakylvö Vieskan Metallin suorakylvökoneella. Lannoitus perustuu kunkin koekentän maalaji- ja viljavuustietoihin sekä lajikkeiden suosituksiin. Kevätviljojen siemenmäärä on tavanomaisen kylvön suositusten mukainen. Suorakylvetyn rypsin siemenmäärä kaksinkertaistettiin v. 2003, jotta saavutettaisiin jyrsinkylvöä vastaava kasvutiheys.

Suorakylvön soveltuvuutta eri kevätviljalajien kylvöön tutkitaan monivuotisessa kenttäkokeessa. Kevätviljalajit ja -lajikkeet ovat monitahoinen ohra (Rolfi), kaksitahoinen ohra (Saana), kaura (Roope) ja kevätvehnä (Kruunu). Sama kylvömenetelmä ja viljalaji toistuvat vuosittain samoilla ruuduilla. Koe aloitettiin v. 2001, mutta liian aikaisin tehdyn suorakylvön vuoksi aloitusvuoden satotuloksia ei tässä artikkelissa käsitellä.

Suorakylvön ajoitusta on tutkittu v. 2002 ja 2003 Saana -ohralla ja Valo -rypsillä, vertaamalla normaaliaikaan tehtyä jyrsinkylvöä samaan aikaan tehtyyn suorakylvöön sekä aikaisempaan ja myöhäisempään suorakylvöön. Aikainen suorakylvö tehdään heti, kun se on teknisesti mahdollista. Viimeinen suorakylvö on pyritty tekemään maan ollessa kylvön kannalta optimaalisessa tilassa, jolloin maa murentuu ja peittää hyvin siemenen.

Kasvustoista määritetään kasvitiheydet, biomassan määrä tietyissä vaiheissa ja peittävyys. Kasvien kasvuasteet määritetään kolmesti viikossa. Jyvä- ja siemensadon määrä mitataan sekä kunkin kasvilajin tärkeimmät laatutekijät määritetään.

\section{Tulokset ja tulosten tarkastelu}

\section{Viljojen kehitysrytmi ja kasvuolojen merkitys}

Kylvöaikojen vertailua hankaloittaa se, että eri koejäsenten kasvuvaiheet ajoittuvat eri tavalla lämpöja kosteusoloihin nähden. Myös silloin, kun suorakylvö ja perinteinen kylvö pyritään tekemään kylvöalustan ollessa parhaimmillaan, voi tietty kasvuvaihe osua eri menetelmillä hyvin erilaisiin oloihin. Näitä kylvöajoista johtuvia eroja myöhemmissä kehitysvaiheissa pyritään arvioimaan tarkalla kasvien kehityksen seuraamisella ja säätietojen tarkastelulla. Toisaalta tutkimus on jo osoittanut, että suorakylvö voi reagoida poikkeuksellisiin säihin tavanomaista kylvöä voimakkaammin.

Viljojen kehitysrytmistä on olemassa tarkat tiedot kahdelta viime kesältä, jotka muistuttivat sääoloiltaan toisiaan. Molempina kasvukausina pääosa sateista tuli alkukesällä, kun loppukesää leimasivat helle ja kuivuus. Vuonna 2002 loppukesän olot nopeuttivat oleellisesti suorakylvettyjen ohrien ja kauran jyvän täyttymistä, myös lämpösummin mitaten. V. 2003 ilmiö oli pikemminkin päinvastainen, kun lämpöä "kului hukkaan" suorakylvettyjen viljojen tullessa tähkälle kovassa helteessä, $6{ }^{\circ} \mathrm{C}$ lämpimämmässä kuin jyrsinkylvetyt viljat. Vuorokausina mitaten oli suorakylvettyjen viljojen loppukehitys v. 2002 selvästi nopeampaa kuin jyrsinkylvettyjen, mutta v. 2003 ei kasvunopeudessa ollut isoja eroja (kuva 1). 


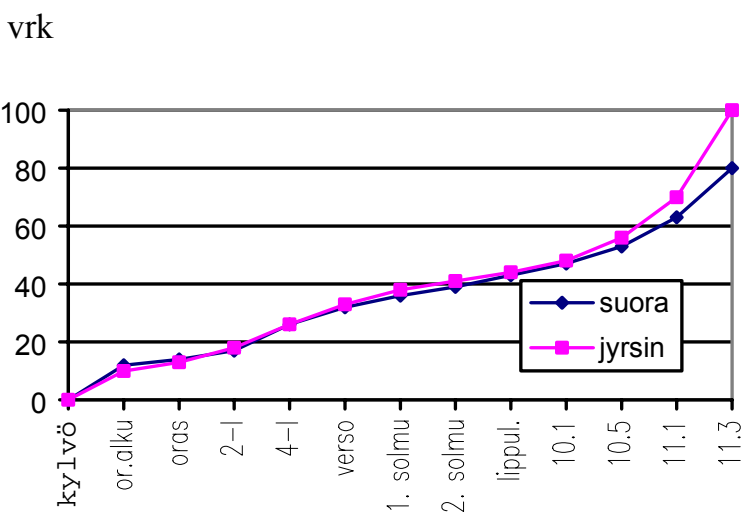

2002 vrk

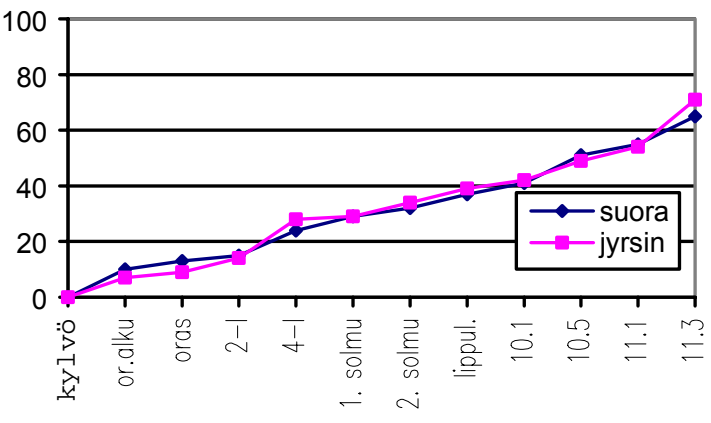

2003

Kuva 1. Monitahoisen Rolfi -ohran kehitysrytmi (Feekesin asteikko) suora- ja jyrsinkylvettynä v. 2002 ja 2003. 10.1 = tähkä alkaa tulla esiin, 10.5 = täysi tähkä, $11.1=$ jyvä maitotuleentunut, $11.3=$ jyvä keltatuleentunut.

Viime kesän poikkeuksellisen kova hellejakso ajoittui viljalajikokeessa suorakylvön kannalta epäedullisemmin. Helteet alkoivat, kun suorakylvetyt viljat olivat lippulehtivaiheessa tai tulossa siihen, kun taas jyrsinkylvetyt olivat jo tulossa tähkälle. Toisaalta hellettä kesti molemmilla kylvötavoilla vähintään maitotuleentumisen vaiheille. Se, että suorakylvetyt viljat joutuivat kärsimään pidempään ankarasta helteestä, lisäsi todennäköisesti kylvötapojen välistä satoeroa mutta ei missään tapauksessa aiheuttanut sitä kuin pieneltä osaltaan.

Kylvöaikakokeessa helle ajoittui aikaisen suorakylvön kannalta muita edullisemmin eli alkoi, kun ohra oli jo melkein täydellä tähkällä. Jyrsinkylvetyllä ja samoihin aikoihin suorakylvetyllä helle alkoi vähän ennen kuin tähkä työntyi esiin sekä viivytetyllä suorakylvöllä vähän ennen lippulehtivaihetta. Toisaalta aikainen suorakylvö kärsi tuholaisten aiheuttamista vioituksista.

\section{Kasvutiheys}

Kylvöaikakokeen ensimmäinen kylvö tehtiin heti kun se oli teknisesti mahdollista, jolloin savimaahan jää helposti myös avonaisia kylvövaon kohtia. Näin kävi vuonna 2003, mutta vuonna 2002 vako peittyi märkänäkin hyvin, maan erilaisen rakenteen ansiosta. Viime kesänä ongelmia aiheuttivat myös puimurin jättämät olkikaistat, joiden kohdalla siemen jäi olkien sekaan kylvövantaan painamaan uraan, sitä helpommin mitä aikaisemmin kylvö tehtiin. Runsaat sateet kylvön jälkeen kuitenkin pelastivat orastumisen (kuva 2).

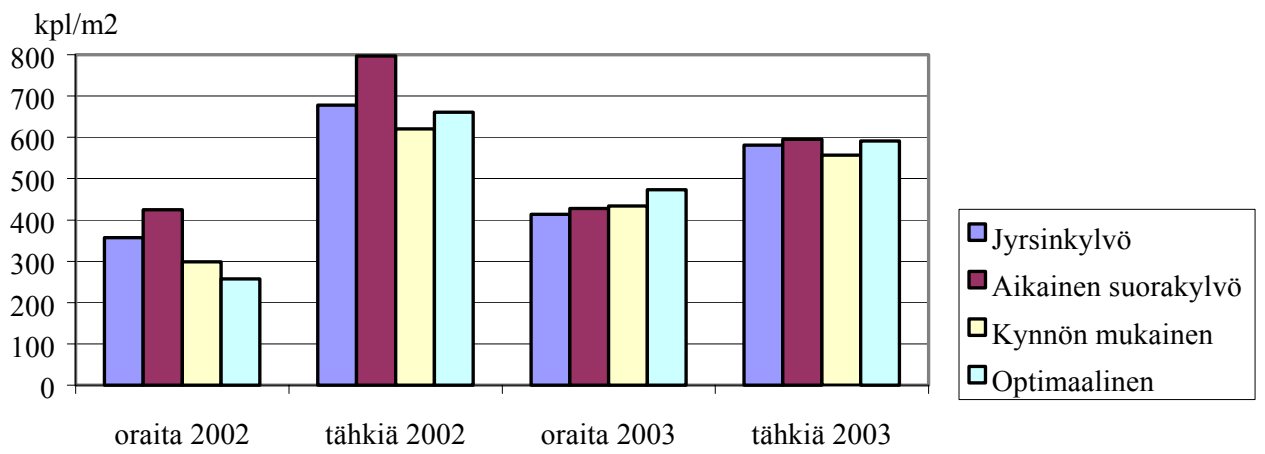

Kuva 2. Kaksitahoisen Saana -ohran oras- ja tähkätiheydet v. 2002 ja 2003 perinteisesti kylvettynä ja eri aikoina suorakylvettynä. Aikainen suorakylvö = heti kun teknisesti mahdollista, kynnön mukainen = aika määräytyy kynnöksen kylvökunnon eli jyrsinkylvön mukaan, optimaalinen = ajankohta määritetään suorakylvettävän maan kosteuden ja murenevuuden perusteella. 


\section{Jyväsadon mä̈̈rä ja laatu}

Ohrien herkkyys vaikeille sääoloille korostuu suorakylvössä, ainakin siirtymävaiheessa. Tämä näkyi jo v. 2001, kun Saana-ohra kellastui orasvaiheen sateissa, mutta muissa viljoissa ei näkynyt oireita. Suorakylvö tehtiin tuolloin liian aikaisin, liian kosteaan maahan. Alkukesän sateiden aiheuttamaa ohrien kellastumista ja heikkokasvuisuutta ilmeni myös v. 2003, vaikka kylvön ajoitus onnistui hyvin. V. 2002 taas loppukesän helle pienensi suorakylvettyjen ohrien jyväkokoa. Kesän 2003 suorakylvettyjen ohrien heikot sadot johtuivat yleisestä heikkokasvuisuudesta, mutta myös rikkakasveilla ja etenkin Rolfin taudeilla oli huomattava merkitys. Kaura ja myös kevätvehnä sopeutuivat suorakylvöön paremmin, mikä näkyi kilpailukykyisempänä jyväsatona sekä yhtä suurina 1000 jyvän ja hehtolitran painoina kuin jyrsinkylvössä (kuva 3).
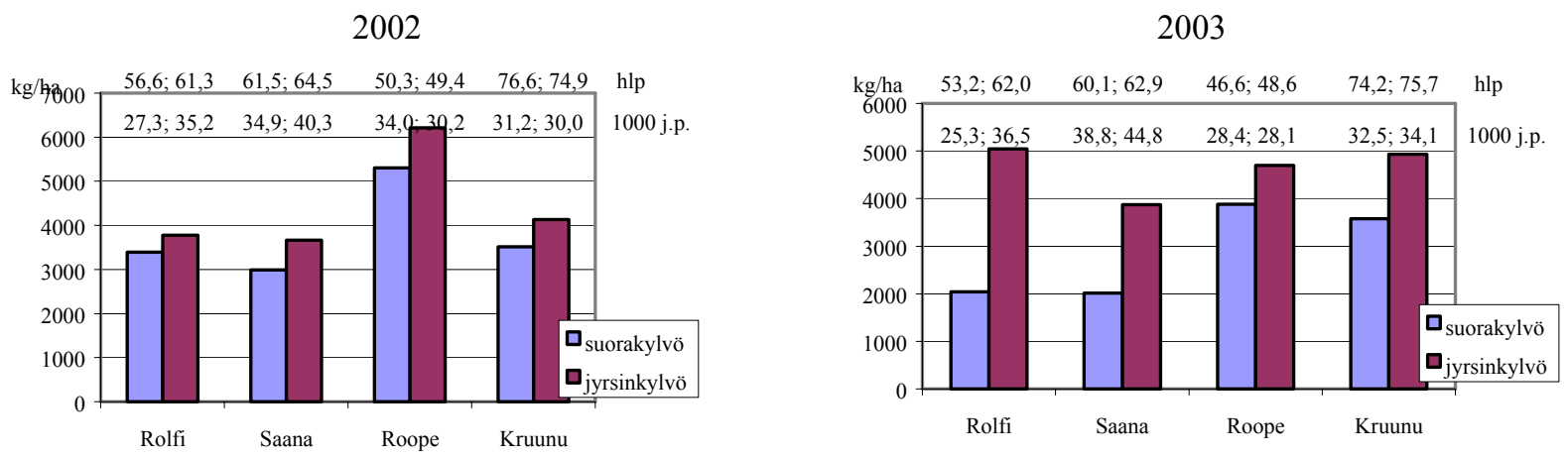

Kuva 3. Monitahoisen ohran (Rolfi), kaksitahoisen ohran (Saana), kauran (Roope) ja kevätvehnän (Kruunu) jyväsato $\left(\mathrm{kg} \mathrm{ha}^{-1}\right)$, hehtolitran paino $(\mathrm{kg})$ ja 1000 jyvän paino $(\mathrm{g})$ suora- ja jyrsinkylvettynä vuosina 2002 ja 2003.

Kylvömenetelmä vaikuttaa muutenkin viljan laatuun. Mallasohran lajitejakaumaan suorakylvö on kokeissa vaikuttanut epäedullisesti, mutta valkuaispitoisuuteen myönteisesti eli pienentävästi. Vastaavasti myös kevätvehnän valkuaispitoisuus oli v. 2002 suorakylvettynä $12,6 \%$ ja jyrsinkylvettynä 13,9 \%. Sakolukuun ja kosteaan sitkoon kylvötavalla ei ollut vaikutusta. Vuoden 2003 sadosta ei leipäviljan laatumäärityksiä ole vielä tehty.

Suorakylvetty Saana-ohra on menestynyt selvästi paremmin jyrsinkylvöön nähden kylvöaikakokeissa kuin viljalajikokeessa. Kasvupaikalla on siis iso merkitys, vaikka kaikki tässä esitetyt kokeet on tehty savimailla. Jyrsinkylvön kanssa samaan aikaan tehty suorakylvö on tuottanut keskimäärin saman suuruisen sadon kuin jyrsinkylvö. Suorakylvön optimiajankohdan hakeminen maan murenevuuden ja kosteuden perusteella ei kumpanakaan vuonna johtanut muita kylvöjä isompaan jyväsatoon. V. 2002 suorakylvö pienensi jyväkokoa kylvöajasta riippumatta ja v. 2003 aikaisin suorakylvetyn Saanan hehtolitran paino oli 5-7 kg isompi kuin muiden kylvöjen. (Kuva 4)

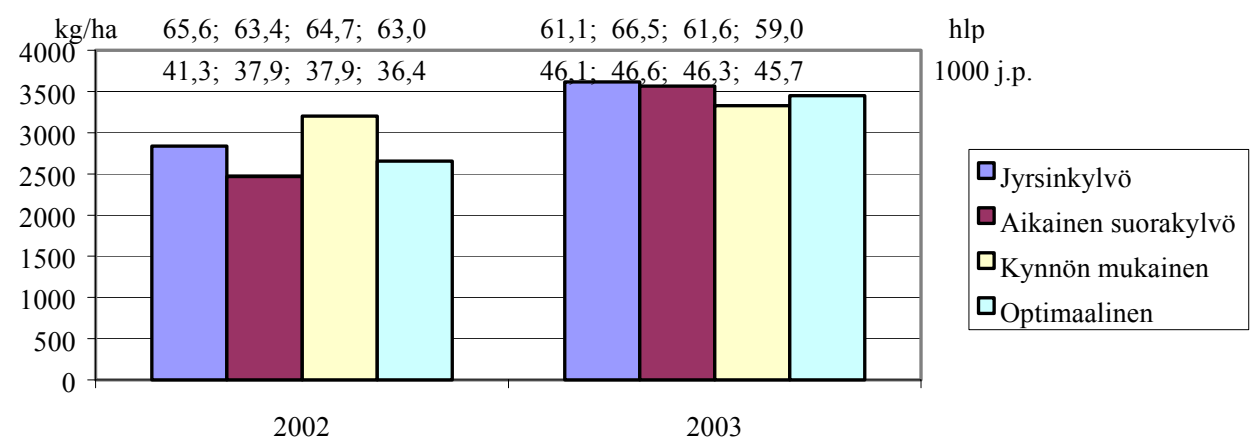

Kuva 4: Kaksitahoisen Saana -ohran jyväsato $\left(\mathrm{kg} \mathrm{ha}^{-1}\right)$, hehtolitran paino ( $\mathrm{kg}$ ) ja 1000 jyvän paino (g) perinteisesti kylvettynä (jyrsinkylvö kynnökseen) sekä eri aikoina suorakylvettynä. Aikainen suorakylvö = heti kun teknisesti mahdollista, kynnön mukainen = aika määräytyy kynnöksen kylvökunnon eli jyrsinkylvön mukaan, optimaalinen = ajankohta määritetään suorakylvettävän maan kosteuden ja murenevuuden perusteella. 


\section{Rypsi suorakylvettynä}

V. 2002 todettiin, että rypsin siemen on vaikeaa saada taimettumaan suorakylvettynä yhtä hyvin kuin perinteiseen tapaan kylvettynä. Samaan aikaan jyrsinkylvön kanssa tehty suorakylvö vähensi taimettumisen puoleen ja vain aikaisin märkään maahan suorakylvetyn rypsin taimitiheys oli lähellä jyrsinkylvetyn rypsin taimitiheyttä. Lounais-Suomen tutkimusasemalla lannoittamaton suorakylvetty rypsi taimettui yhtä hyvin kuin tavanomaisesti kylvetty. Talvella tehdyssä astiatestissä todettiin lannoiterakeiden estävän rypsin siementen itämistä. V. 2003 käytettiin suorakylvössä kaksinkertaista siemenmäärää menetelmien vertailtavuuden parantamiseksi. Taimitiheys ja myöhempi kasvitiheys olivatkin sen ansiosta kaikissa suorakylvöajoissa lähes samoja kuin jyrsinkylvössä. Edellisen kasvin, kauran, oljet haittasivat eniten aikaisessa kylvössä, jossa toisaalta taimettuminen paljaassa maassa oli hieman parempaa kuin muissa kylvöajoissa. Hyvään taimettumiseen auttoivat alkukesän sateet. Taimia tuli myös sellaisiin kohtiin, joissa siemen jäi oljen joukkoon, kapeaan avoimeen vakoon.

V. 2002 rypsin siemensato oli huono, alle $900 \mathrm{~kg} \mathrm{ha}^{-1}$, kylvötavasta riippumatta. Jyrsinkylvön kanssa samaan aikaan suorakylvetty rypsi pystyi kompensoimaan huonoa taimettumistaan niin, että sato oli lähes sama kuin jyrsinkylvettynä. Sen sijaan myöhäisen kylvön heikko taimettuminen johti erittäin huonoon ja rikkaruohoiseen kasvustoon.

Rypsin kylvöaikakokeissa erilaisten olojen merkitys rypsin kasvulle oli huomattava. Esimerkiksi kirpat ovat olleet eniten aikaisten kylvöjen riesana, mitä koeoloissa paikataan ruiskutuksin aina kun on tarpeen. V. 2003 aikaisin kylvetty rypsi kasvoi edullisemmissa oloissa kuin muut, jotka olivat kukintavaiheessa kovan helteen aikaan. Aikaisin suorakylvetyn rypsin kasvuaika olikin kymmenen vuorokautta pidempi kuin muiden kylvöjen ja kukinta kesti kolme viikkoa, kun se muilla kesti vain kaksi viikkoa. Toisaalta aikainen suorakylvö kärsi mustalaikkutaudista, joka aiheutti palkojen mustumista ja siementen kehittymättömyyttä. Aikaisin suorakylvetyn rypsin siemensato oli lopulta $\mathrm{n} .1600 \mathrm{~kg} \mathrm{ha}^{-1}$, kun se jyrsinkylvettynä ja samaan aikaan suorakylvettynä oli $\mathrm{n} .1450 \mathrm{~kg} \mathrm{ha}^{-1} \mathrm{ja}$ ns. maan kannalta optimiaikaan suorakylvettynä n. $1300 \mathrm{~kg} \mathrm{ha}^{-1}$.

\section{Johtopäätökset}

Savimaiden suorakylvö on sääoloille herkempi menetelmä kuin perinteinen muokattuun maahan tehty kylvö. Ohran jyväsadon määrä ja laatu kärsii helpommin alkukesän märkyydestä tai loppukesän kuivuudesta kuin muiden kevätviljojen. Kaura on tuottanut varmimmin määrältään kohtalaisen ja laadultaan hyvän sadon. Ensimmäiset kokemukset kevätviljan suorakylvöstä onkin riskittömintä hankkia kauralla. Lannoitteen sijoittaminen samaan vakoon siemenen kanssa ei ole haitannut orastumista.

Suorakylväen on vaikeampaa perustaa rypsikasvusto kuin viljakasvusto. Savimaa voi kuivua pinnasta liian kovaksi matalaa $(2-3 \mathrm{~cm})$ kylvöä ajatellen. Toisaalta liian märässä maassa siemenen päälle painunut tiukka savi voi olla kuivuttuaan liian kova este pintaan pyrkivälle kasville. Vaikka alkukesän sateet auttoivatkin, osoitti viime kesä, että suorakylväen on mahdollista perustaa hyvä rypsikasvusto. Lannoittamiseen on kuitenkin saatava sellainen ratkaisu, että taimettuminen ei lannoitteen vuoksi heikkene. Kunnollisen taimettumisen jälkeen muut tekijät kuin kylvötapa ratkaisevat usein rypsin sadon.

Kokeet on perustettu pelloille, jotka on aiempina vuosina kynnetty. Monivuotisessa viljalajikokeessakin kyse on vasta siirtymävaiheesta, jossa ainakaan vielä kolmantena vuonna ei näkynyt merkkejä suorakylvettyjen alueiden kasvuedellytysten paranemisesta. Syyt suorakylvetyn ohran erilaiseen menestymiseen eri koealueilla vaativat selvittämistä. Lisäksi koevuosille ei ole osunut Jokioisten seudulle tyypillistä kuivaa alkukesää, jossa suorakylvö kosteutta säästävänä menetelmänä voi olla edukseen.

Viljalajikokeessa viljellään koeteknisenä kompromissina samoja lajeja samoilla ruuduilla, mikä korostanee ainakin ohran tautien merkitystä. Rypsin saaminen mukaan viljelykiertoon olisi toivottavaa jo seuraavan kasvin helpon kylvönkin kannalta. Luotettavan kauran kohdalla taas on kiinnitettävä erityistä huomiota olkiongelmien vähentämiseen seuraavaa kasvia ajatellen. Monipuolisen viljelykierron toteutuminen myös suorakylvöä käyttävillä tiloilla onkin yksi tutkimuksen haasteista tulevina vuosina. 